\title{
犬の気腹造影法の検討
}

小池寿男* 松橋 哠* 大友勘十郎* 酒井 保*

(昭和 46 年 7 月 5 日受付)

\section{Examination of Pneumoperitoneum in the Dog}

T. Koike, A. Matsuhashi, K. Отомо, T. SaKai (Department of Veterinary Surgery, Faculty of Veterinary Medicine, Hokkaido University, Sapporo 060)

\section{SUMMARY}

A technique for pneumoperitoneum in the dog was examined. The air insufflation of $50 \mathrm{ml}$ per $\mathrm{kg}$ of body weight in the abdominal cavity was fit for pneumoperitoneum in the dog. A dog was placed, in the head-up or head-down position, on a table that tilted at an angle of 45 degrees.

This technique was applied to 18 clinical cases. Air

犬の軟部組織の X線診断は人の場合と異なり, 骨疾患 の診断ほどその頻度は高くない.腹部臓器のX線診断も 単純撮影像では異物・腸閉塞・子宮蓄膿症などの診断に 用いられているが，その他の場合はX線吸収差が少ない ことからその診断には相当の熟練を要している。また, 腹部の造影法は犬では消化管への硫酸バリウムおよび泌 尿器へのヨー素系造影剂の利用などが行なわれているに すぎない。

腹腔内藏器の形態的変化を明らかにする造影法の一つ に従来から人では気腹法が用いられ，放射性同位元素を 用いる診断法の普及しない15年前までは比軟的よく利用 されていた. 本法は1913 年 WEBERによってはじめて 用いられ, 造影法としては古いものである。造影剤とし ては, 酸素・炭酸ガス・空気なぞが用いられている. 比 較的簡単な手技によって行ない得るにもかかわらず, 本 法の犬への利用については, SChNelle (1950), CARlson (1957), Douglas(1963)らの簡単な記述があるのみで, 気腹の基準, 副作用などについては不明瞭な点が多い. 今回著者らは犬の気腹造影法についての基本的な 2,3 の点について観察し, 興味ある知見を得たので, その概 要について報告する.

\section{実験材料および方法}

\section{1. 実験材料}

基礎的な検討には臨床上異常を認めない雑種犬 17 頭 （体重 $6.0 \sim 15.0 \mathrm{~kg}$, 年路 6 力月ないし 10 才, 雌 12 , 雄 5 ）を用い，いずれる $12 \sim 18$ 時間絶食後実験に供し た。

臨床例は 18 頭で, いずれも昭和 43 年 2 月から昭和 44年 8 月までに北海道大学獣医学部付属家畜病院に来院

* 北海道大学獣医学部（札幌市中央区北 18 条西 9 丁目） insufflated into the abdominal caviy was absorbed at the rate of 30 or $50 \mathrm{ml}$ per day. Pneumoperitoneum in this experiment had no side effects on the clinical findings.

It was suggested that pneumoperitoneum might be a useful method for examination of the abdominal structures in the dog.

\section{した患犬である。}

\section{2. 実験方法}

a. 器 具

X線装置は東芝放射線株式会社製 $\mathrm{KXO}-15$ 型を用 い,フィルムは富士 X線フィルム 4 ッ切版ないし 8 ッ切 版を, また, 増感紙は極光 FS 型あるいは H.S 型を用 いた，空気の注入には, 著者らがすでに報告した乳房造 影法に用いた水圧式注入装置を，また，血圧・呼吸・心 電図の観察には日本光電株式会社製多用途監視記録装置 を用いた。

b. 気腹造影法

実験例については, ペントバルビタール・ナトリウム (ネンブタール） $25 \mathrm{mg} / \mathrm{kg}$ の静脈内注射により麻酔し, 5 分後仰臥位に保定し臍の後方 $2 \sim 3 \mathrm{~cm}$ の部を法のごと く消毒した．ついで大型輸血針を前背方に約 45 度の角 度で刺入し, 注射器を用いて吸引して血管あるいは腹腔 内臓器に刺入していないことをたしかめたのち注入装置 に連結して, 体重 $\mathrm{kg}$ 当たり 20〜130 ml の沪過した空気 を徐々に注入した。

X 線撮影台には大用手術台を用いた. 腹腔内に所要の 空気を注入したのち, 頭部を上にした位置(頭位と略称) あるいは頭を下にした位置（尾位と略称）でそれぞれ手 術台を 45 度傾斜させ犬の側方特よび腹背方向に垂直の 方向からX線を照射撮影した. また, 駐立状態（立位と 略称）においては側方から撮影した.

撮影条件は焦点フィルム距離 $120 \mathrm{~cm}$, 管球電圧 $60 \mathrm{kv}$, 管球電流 $100 \mathrm{~mA}$, 照射時間は大の大きさにより FS 型 増感紙使用の場合は 8/1C0 14/100 秒, H. S 増感紙使用 の場合は 6/100〜10/100 秒とした.

撮影後 5 頭は空気を抜去することなく放置し，10～30 日の間適宜 $X$ 線撮影をなして空気の吸収状態をしらべ 
小池寿男 松橋 晧

た.との他は撮影終了後注射針を再刺入して大部分の空 気を抜去した。

なお,一部の例では硫酸バリウムゾルを内服 $(10 \mathrm{~m} l / \mathrm{kg})$ あるいは注腸 $(50 〜 100 \mathrm{ml})$ して腸管の位置を観察した.

\section{c . 気腹の影響検査}

気腹の影響は一般状態のほか，血圧・呼吸および心電 図について検討した，実験用犬は，全身麻酔後手術台上 に右側臥，左側臥および仰卧位に保定し，右あるいは左 股動脈を裸出し，カニューレを挿入して電気血生計に結 び, 第 7 胸椎部および第 4 腰椎部に三栄測器製胸团型呼 吸曲線ピックアップを装置し,さらに第 2 肢誘導による 電極を装置し, それぞれ多用途監視記録装置に結んで記 録した。

これらは, 術前・空気注入中および注入後体位を変換 しつつ連続して記録し,さらに脱気後も観察した。なお 腹腔内圧は注入装置の圧力計の表示によった。

d. 臨床例

臨床例については 18 例中 15 例は無麻酔のまま, 3 例は全身麻酔下でいずれも仰卧位において，実験例に準 じて空気を注入したのちX線撮影を行なった。

\section{1. 空気量とX線像}

\section{実 験 結 果}

気腹した犬の $\mathrm{X}$ 線像で明視できる臟器は撮影体位, 撮 影方向および空気量によって異なり，その結果を示すと 表 1 のらである.

すなわち, 頭位で, 空気注入量 $25 \mathrm{ml} / \mathrm{kg}$ の像では腹 背像において肝の外側左葉を区別できる場合もあるが, 多くは肝の各葉は区別することは出来なかった. $50 \mathrm{ml} / \mathrm{kg}$ 以上を注入した場合は, 肝は 6 葉中外側右葉・内側右葉・ 尾状葉および外側左葉を明らかに区分することができ た. 時として内側左葉も認められるが，方形葉を区分す ることはできなかった。そその他の臓器では腎および横隔 膜がよくわかり，時には胃を区分することができた。
大友勘十郎 酒井 保

尾位では空気注入量 $25 \mathrm{~m} / \mathrm{kg}$ 像において膀胱および 直腸の陰影を区分することができたが，子宮は $50 \mathrm{~m} l / \mathrm{kg}$ 以上の量を注入した場合でも病的なもの以外はその㓌影 を認め得ることは少なく，とくに未経産犬では注とんど その㓌影を区分できなかった。

立位では空気注入量が $25 \mathrm{~m} l / \mathrm{kg}$ では腎の限界がやや 不明瞭であったが, $50 \mathrm{ml} / \mathrm{kg}$ 以上ではその外形が明らか となった，子宮角は尾位側面像の場合と同様に，病的な もの以外は認めることが困難であった.

空気の注入量が $75 \sim 100 \mathrm{ml} / \mathrm{kg}$ の像にあっても X線像 に和ける各臓器の区分は $50 \mathrm{ml} / \mathrm{kg}$ の場合とほとんどか わらないが空気の下縁もほとんど差がなく単に腹囲の膨 大を示すのみであった.

\section{2. 体位と内臓の位置}

体位の変換にともなって位置の変化が著しい蔵器は腸 管であり, 気腹しない場合でもかなりの差がある. 空気 注入量が $50 \mathrm{ml} / \mathrm{kg}$ の気腹時において頭位と尾位では水 平横臥時に比べて椎骨の高さで $2 \sim 4$ בの移動があり, とくに尾位では第 3 腰椎より後方は直腸・子宮および膀 胱のみとなる。

横行結腸は気腹前は小腸の背側で, ほぼ最後胸椎の下 を右から左へ走っているが，気腹後は椎骨の高さで約 2 コ上下した，その走行も右背側から左腹側に斜下方に走 る.したがって下行結腸は左下方から背後方に走るよう になった．この大腸の変位はとくに頭位の場合に著しか った.

子宮角は尾位側面像では直腸と膀胱の間に認められた が，立位側面像では直腸と交叉し腎への直後から鈎状の 形をとって認められた。

\section{3. 腹圧・血圧・脈搏・呼吸および心電図}

腹圧は空気の注入量にともない $5 \sim 14 \mathrm{mmHg}$ の間の変 動があり，右側卧および左側卧位では注入量にともなっ

表 1 空気注入量と $\mathrm{X}$ 線像

\begin{tabular}{|c|c|c|c|c|c|c|c|c|c|c|}
\hline \multirow{2}{*}{ 撮影体位 } & \multirow{2}{*}{\multicolumn{2}{|c|}{ 提入量 $\mathrm{ml} / \mathrm{kg}$}} & \multicolumn{2}{|c|}{25} & \multicolumn{2}{|r|}{50} & \multicolumn{2}{|l|}{75} & \multicolumn{2}{|c|}{100} \\
\hline & & & 空気下縁 & 区分臓器 & 空気下縁 & 区分臓器 & 空気下縁 & 区分臓器 & 空気下縁 & 区分臓器 \\
\hline \multirow{2}{*}{ 傾斜頭位 } & 腹 & 背 & 第13胸椎 & 肝 上縁 & 第 2 腰椎 & $\begin{array}{l}\text { 肝(葉間分離) } \\
\text { 㹂(やや不明) } \\
\text { 横隔膜 }\end{array}$ & 第 4 腰椎 & $\begin{array}{l}\text { 肝(葉間分 } \\
\text { 腎 } \\
\text { 横隔膜 }\end{array}$ & $\begin{array}{l}\text { 離) } \text { 肝 } \\
\text { 第 } 4 \text { 腰椎 }\end{array}$ & $\begin{array}{l}\text { （葉間分離） } \\
\text { 㹂 } \\
\text { 横隔膜 }\end{array}$ \\
\hline & & & "I & 肝 - 腎 & "I & $\begin{array}{l}\text { 肝(葉間分離) } \\
\text { 腎(やや不明) } \\
\text { (胃) }\end{array}$ & 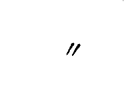 & $\begin{array}{l}\text { 肝(葉間分 } \\
\text { 腎 } \\
\text { (胃) }\end{array}$ & 離） 肝 & $\begin{array}{l}\text { （葉間分離） } \\
\text { 督 } \\
\text { （胃） }\end{array}$ \\
\hline \multirow{2}{*}{ 傾斜尾位 } & 腹 & 背 & 第 3 腰椎 & $\begin{array}{ll}\text { 膀 } & \text { 胱 } \\
\text { 子 } & \text { 宮) }\end{array}$ & 第 1 腰椎 & $\begin{array}{ll}\text { 膀 } & \text { 脱 } \\
(\text { 子 } & \text { 宮) }\end{array}$ & 第 1 腰椎 & $\begin{array}{l}\text { 膀 胱 } \\
\text { (子宮) }\end{array}$ & 第 1 腰椎 & $\begin{array}{l}\text { 膀 胱 } \\
\text { (子宮) }\end{array}$ \\
\hline & & & "I & $\begin{array}{l}\text { 膀脂・直腸 } \\
(\text { 宮) }\end{array}$ & "I & $\begin{array}{l}\text { 膀胱・直腸 } \\
(子 \text { 宮) }\end{array}$ & "1 & $\begin{array}{c}\text { 膀胱・直腸 } \\
\text { (子宮) }\end{array}$ & "I & $\begin{array}{c}\text { 膀胱・直腸 } \\
(\text { 子宮 }\end{array}$ \\
\hline 駐 & & & 上 $1 / 3$ & $\begin{array}{l}\text { 腎の限界 } \\
\text { やや不明 }\end{array}$ & 上 $1 / 3$ & $\begin{array}{l}\text { 腎 - 直腸 } \\
\text { (子 宮) }\end{array}$ & 上 $2 / 3$ & $\begin{array}{l}\text { 腎・直腸 } \\
\text { (子宮) }\end{array}$ & 上 $2 / 3$ & $\begin{array}{l}\text { 篎・直腸 } \\
\text { (子宮) }\end{array}$ \\
\hline
\end{tabular}


図 1 腹圧の変動(各体位 5 例平均值)

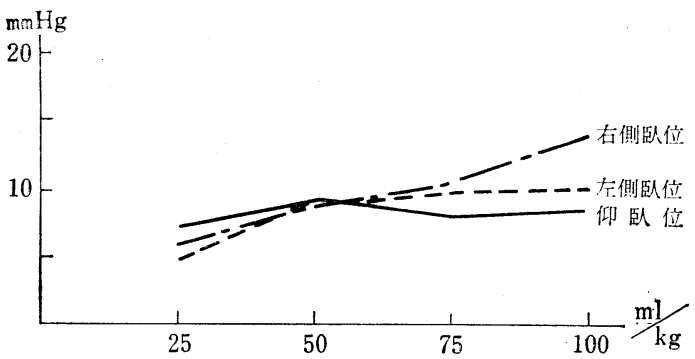

図 2 血圧の変動（各体位 5 例平均值）
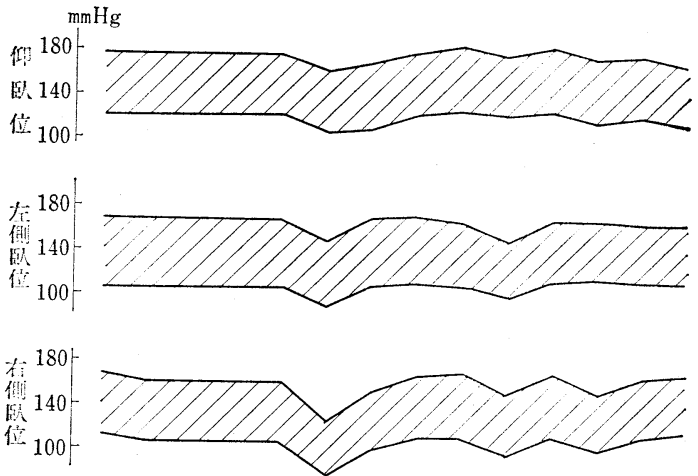

\begin{tabular}{|c|c|c|c|c|}
\hline \multicolumn{2}{|l|}{ 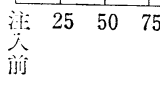 } & $\begin{array}{l}100 \text { 尼 } \\
\frac{\mathrm{ml}}{\mathrm{kg}} \text { 位 }\end{array}$ & & 供 \\
\hline
\end{tabular}

て増加の傾向を認めたが，仰臥位ではこの傾向は明膫で はなかった。

気腹による血圧の変化はいずれの体位でも注入中はと くに変化を認めることはできなかったが，体位の変換に ともなって若干の変動を示した．すなわち頭を下げる時 ならびに頭を上げるときに一過性の血圧下降があり，気 腹前の值を 100 とした変動率は尾位仰臥位 9.16 , 左側 卧位 14.17, 右側臥位 $26.65 \%$ であり，頭位ではそれぞ れ 5.57. 13.20 および $14.69 \%$ であった. 全経過中, 脈圧には著変は見られなかった。

呼吸数は気腹により若干増加し，とくに仰臥位で明ら かであった．体位の変換にともなら変化としては，頭を 下げると增数し，復位により旧に復し，頭を上げると減 少したが，復位によりふたたび增数し，脱気によりほぼ 注入前の值にもぞった。

脈搏数は，気腹のみによっては影響されることが少な く, 右側臥ではやや減数さえ示していた程度であった。 注入後の体位の変換によってはいずれの場合も增数し, 多小の動摇を示したが, 脱気によってほぼ注入前の值に もどった。

心電図は波形の上ではQR S の変化，すなわち高さの 変動が目立ち，一般に気腹によって軽度の低下があり，
図 3 血圧变動率（各体位 5 例平均值）

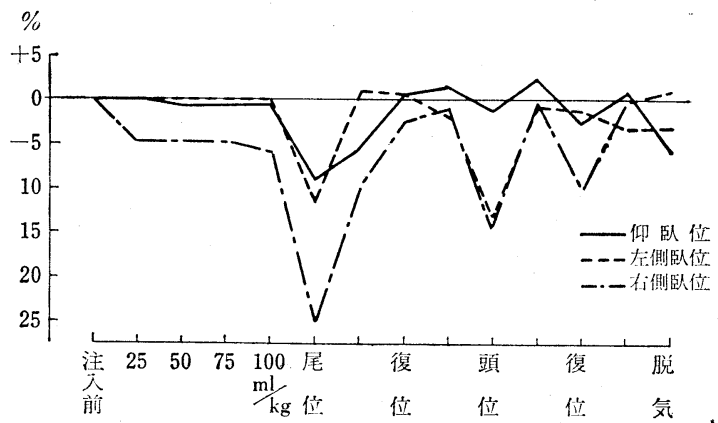

図 4 呼吸数と脈搏数の变動（各体位 5 例平均値）
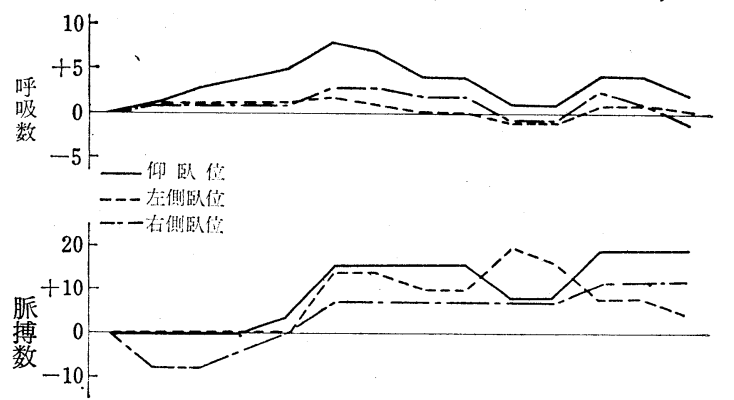

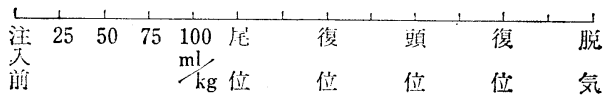

頭を下げると増高し，上げると低くなった。

$700 \sim 1,000 \mathrm{ml}$ 注入された腹腔内の空気は $25 \sim 30$ 日 でX線像に現われなくなり，ほぼ 1 日に 30〜 $50 \mathrm{ml}$ の割 合で吸収されていた。

\section{4. 臨床例}

臨㦿例で気腹造影法を行なった 18 頭の成績は表 2 の ようである。

最も多いのは子宮外形の検査の16頭であり，他は肝・ 腹膜・内臓の外形を目的としたものであった.

子宮角の陰影については太さ約 $3 \mathrm{~cm}$ 以上の例では腹 膜炎で腹水の増量していた No.10 を除いて単純撮影像 に拉いても子宮角を認めることができたが， $1.5 \mathrm{~cm}$ 以 下の太さのものでは尾位側面像および腹背像では不鮮明 な場合が多かった．立位側面像あるいは大腸内へのバリ ウム注入による二重造影法などがその陰影を認めるのに 効果的な場合もあった。

空気の注入量は $11.0 \sim 50.0 \mathrm{ml} / \mathrm{kg}$ の範囲にあり, 無 麻酔下で行なった症例でも空気の注入および撮影にとく に支障はなく，その後も臨床上気腹による影響は認めら れなかった。

空気注入による腹圧は無麻酔下のためやや動摇が見ら れたが，計測できた 6 例では $10 〜 23 \mathrm{mmHg}$ を示してい る. 
小池寿男 松橋 哠 大友勘十郎 酒井 保

表 2 気 腹 造影症 例一覧

\begin{tabular}{|c|c|c|c|c|c|c|c|c|c|c|}
\hline 䎹種 & 性 & $\begin{array}{l}\text { 年齢 } \\
(才)\end{array}$ & 気腹の目的 & $\begin{array}{l}\text { 体重 } \\
(\mathrm{kg})\end{array}$ & $\begin{array}{l}\text { 空気量 } \\
\text { (ml) }\end{array}$ & $\mathrm{ml} / \mathrm{kg}$ & $\begin{array}{l}\text { 注入後 } \\
\text { 腹压 } \\
(\mathrm{mmHg})\end{array}$ & 永影体尾および & 気腹造影像所見 & 摘 \\
\hline 1 スピッッ & P & 4 & 子宮外形 & 6.0 & 200 & 33.3 & - & 复背 & $\begin{array}{l}\text { 太さ約 } 3.5 \mathrm{~cm} \text { の子宮 } \\
\text { 角が屈曲* }\end{array}$ & $\begin{array}{l}\text { 嘔吐·帯下• } \\
\text { 全摘** }\end{array}$ \\
\hline 2 スピッッ & + & $7 \sim 8$ & 子宮外形 & 7.5 & 200 & 26.6 & - & 尾位一側面・腹背 & $\begin{array}{l}\text { 太さ約 } 2 \sim 3 \mathrm{~cm} \text { の連珠 } \\
\text { 綰角 }\end{array}$ & $\begin{array}{r}\text { 帯下・全摘 } \\
* *\end{array}$ \\
\hline 雑 & ㅇ & 4 & 子宫外形 & 10.0 & 500 & 50.0 & $10 \sim 17$ & 尾位一側面・腹背 & $\begin{array}{l}\text { 側面像で太さ約 } 2.5 \mathrm{~cm} \\
\text { 保角 }\end{array}$ & 帯下 \\
\hline 雑 & 우 & 2 & 子宮外形 & 8.0 & 400 & 50.0 & $16 \sim 23$ & 尾位一側面・腹背 & 太さ約 $2 \mathrm{~cm}$ 子宮角 & 帯下 \\
\hline $5=リ-$ & ㅇ & 9 & 子宮外形 & 15.0 & 500 & 33.3 & $20 \sim 22$ & 尾位一側面・腹背 & $\begin{array}{l}\text { 太さ約 } 3 \mathrm{~cm} \text { の子宮角 } \\
\text { 一部不明膫* }\end{array}$ & 出血・全摘 \\
\hline 6 スピッッ & ㅇ & 10 & 子宮外形 & 14.0 & 400 & 28.5 & - & 尾位一側面・腹背 & 太さ約 $2 \mathrm{~cm}$ の子宮角 & 帯下・全摘 \\
\hline 雑 & q & 10 & 子宮外形 & 11.0 & 500 & 45.4 & - & ・腹背 & $\begin{array}{l}\text { 立位㑯面像で太さ約 } 1.5 \\
\mathrm{~cm} \text { 子宮角が直腸影と } \\
\text { 交叉 }\end{array}$ & 5 带T \\
\hline 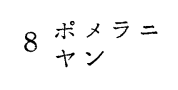 & q & 2 & 子宮外形 & 2.3 & 100 & 43.4 & - & 尾位一側面・腹背 & 子宫角痖着 & $\begin{array}{l}\text { 帯下. } 2 \text { 年 } \\
\text { 前帝王切開 }\end{array}$ \\
\hline ピッツ & $q$ & 11 & 形 & 2.7 & 100 & 37.0 & - & 尾位一側面・腹背 & $\begin{array}{l}\text { 太さ約 } 1.0 \mathrm{~cm} \text { 子宮角 } \\
\text { 一部不明膫 }\end{array}$ & \\
\hline 10 アイヌ & + & 4 & 子宮 & 15.0 & 500 & 33.3 & 20 & 尾位一側面・腹背 & $\begin{array}{l}\text { 太さ 5 6 cm 子宮角屈 } \\
\text { 态 }\end{array}$ & $\begin{array}{l}\text { 帯下・腹膜 } \\
\text { 炎 }\end{array}$ \\
\hline 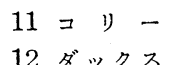 & o & $\begin{array}{c}12 \sim 3 \\
4\end{array}$ & $\begin{array}{l}3 \text { 子宮 } \\
\text { 子宮 }\end{array}$ & $\begin{array}{r}17.0 \\
9.0\end{array}$ & 500 & $\begin{array}{l}29.4 \\
11.1\end{array}$ & 20 & & $\begin{array}{l}\text { 子宮角陰影不明瞭 } \\
\text { 子宮角陰影不明瞭 }\end{array}$ & $\begin{array}{l}\text { 帯下 } \\
\text { 帯下 }\end{array}$ \\
\hline $\begin{array}{l}12 \text { ダックス } \\
13 \text { フヌ }\end{array}$ & 勇 & 4 & 于呂 & 17.5 & 600 & $\begin{array}{l}11.1 \\
34.2\end{array}$ & - & 背 & 太さ約 0. & 带下 \\
\hline 13 アイヌ & 우 & 5 & 于呂 & 17.5 & 600 & 34.2 & & & & バリ \\
\hline 14 & 우 & 一 & 子宮外形 & 10.0 & 500 & 50.0 & - & ・腹背 & $\begin{array}{l}\text { 1. } 0 \mathrm{~cm} \text { 子子宮角明膫に } \\
\text { 直腸と交叉 }\end{array}$ & $\begin{array}{l}\text { 儿注腸によ } \\
\text { る重造影 }\end{array}$ \\
\hline 雑 & 우 & - & 子宮外形 & 14.0 & 700 & 50.0 & - & ・腹背 & 小鷄卵大子宮角陰影 & $\begin{array}{l}\text { 妊娠約 } 30 \\
\text { 日 }\end{array}$ \\
\hline $16 \begin{array}{l}\text { コッカー } \\
\text { スパ=エ } \\
\text { ル }\end{array}$ & 웅 & 8 & $\begin{array}{l}\text { 奣・外宮 } \\
\text { 形 }\end{array}$ & 14.0 & 700 & 50.0 & $10 \sim 20$ & ・腹背 & $\begin{array}{l}\text { 肝は明膫で辺縁平滑 } \\
\text { 子宮角陰影不明膫 }\end{array}$ & 陰部肉腫 \\
\hline 雑 & $\hat{o}$ & 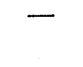 & 腹膜痿着 & 11.0 & 550 & 50.0 & - & 尾位一側面・腹背 & 側面像で瘾着像を認を & $\begin{array}{l}1 \text { 月月前卵宩 } \\
\text { 摘出 }\end{array}$ \\
\hline 18 スピッッ & q & - & 内臟外形 & 7.5 & 350 & 46.6 & - & $\begin{array}{l}\text { 水平位一側面・腹 } \\
\text { 背 }\end{array}$ & 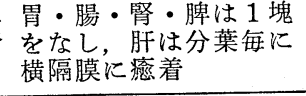 & $\begin{array}{l}\text { 腹膜炎 } \\
4 \text { 年前卵巣 } \\
\text { 摘出 } \\
\end{array}$ \\
\hline
\end{tabular}

註：* 単純撮影像においても子宮角陰影を認めたもの.

** 子宮蓄膿症のため卵巣・子宮全摘出術を行なったもの.

\section{考察ならびに総括}

気腹造影法は手技が比較的簡単で, しかも腹腔内臓器 の形態的な変化を知る上に有効な手段であるにもかかわ らず，犬に適用するための基礎的資料に関する報告は少 ない.空気の必要注入量についても SCHNELLE ${ }^{7,8)}$ は Fox terrier 型の犬で $1,500 \mathrm{~m} l$ 以上と述へ, DougLAs ${ }^{4)}$ は 単に大きさにより 200 1, $000 \mathrm{ml}$ の変化があるとし, CARLSON $^{2,3)}$ は 30 ポンドの犬で $800 \sim 1,000 \mathrm{ml}$ で十分 であるとしている. しかもその基準のきめ方も, 明暸に 示したものはなく，実施上種々の不便がある.

今回の実験で体重を基準としてX線像を対比した結 果, 空気注入量は $50 \mathrm{ml} / \mathrm{kg}$ がほぼ啇当であることを知 った。この量は CARLSON が実験的に必要注入量を決め
るために立位に拈ける腎の概形を認めらるまで透視しな がら注入した場合のX線像所見にほぼ一致している。ま た臨床例についても, 子宮が非常に大きくなっている症 例では HARTUNG ら5が単純撮影法でも認めえたように $25 \mathrm{ml} / \mathrm{kg}$ 前後でも診断に用いることができた. しかし， 小さい子宮では $50 \mathrm{ml} / \mathrm{kg}$ 前後の注入によらなければそ の像が明確でなかったことから臨床上の利用には少なく とも $50 \mathrm{~m} l / \mathrm{kg}$ の空気注入量を基準として用いるのがよい と考える.

撮影体位およびす向について，CARLSON は肝の診断 には直立側位と直立腹背位がよく, 腎の診断には立位側 方向を，子宮では後稫を高くした立位側方向撮影をよい としている.今回は撮影台として小動物手術台を用いる 場合の頭位, 尾位ならびに立位について検討した結果, 
犬の気腹造影法の検討

(1)

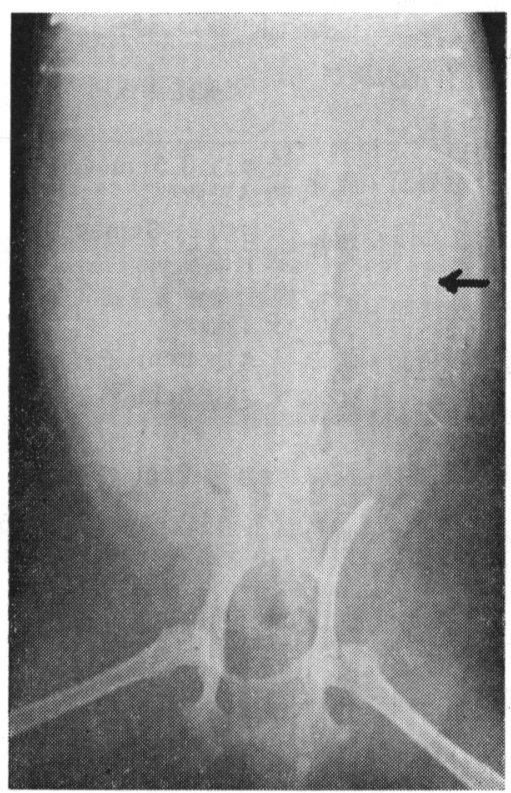

(2)

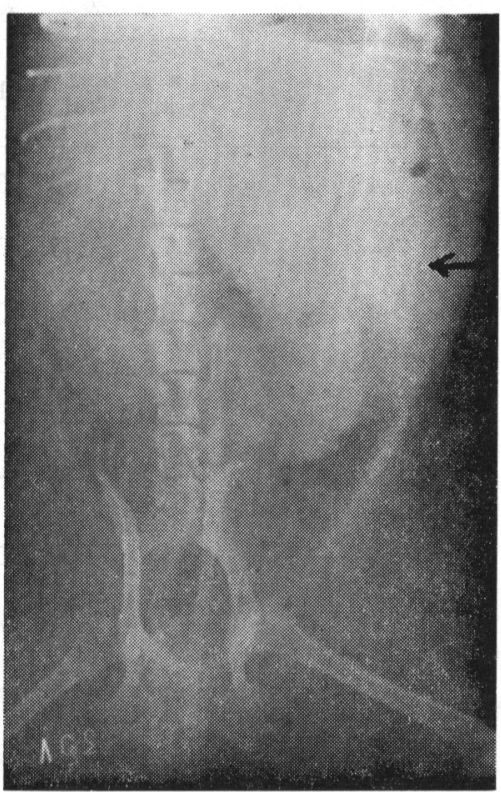

写真 1 子 宮 蓄 膿 症

(1) 気腹前 (2) 気腹後（尿道カテーテル插入）矢印は子宮角を示す.

(1)

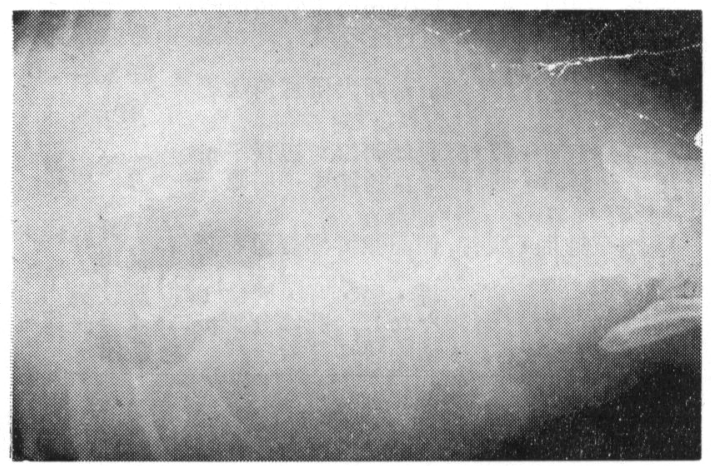

(2)

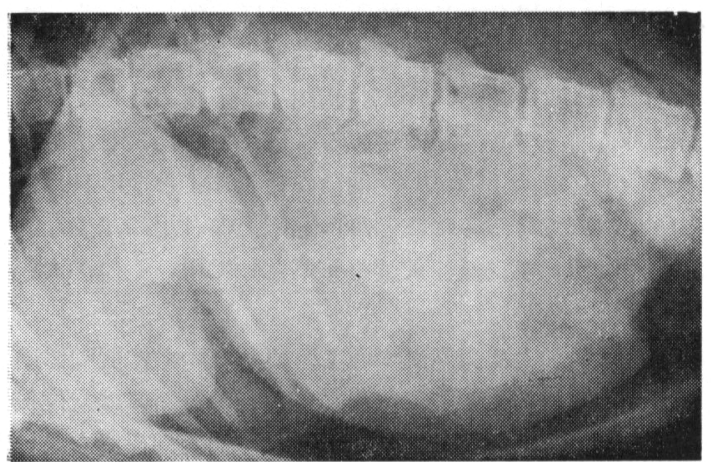

肝・横隔膜は CARLSONの場合に準じた頭位側方向および 腹背方向撮影によって肝の 6 葉中方形葉以外の分葉を区
(3)

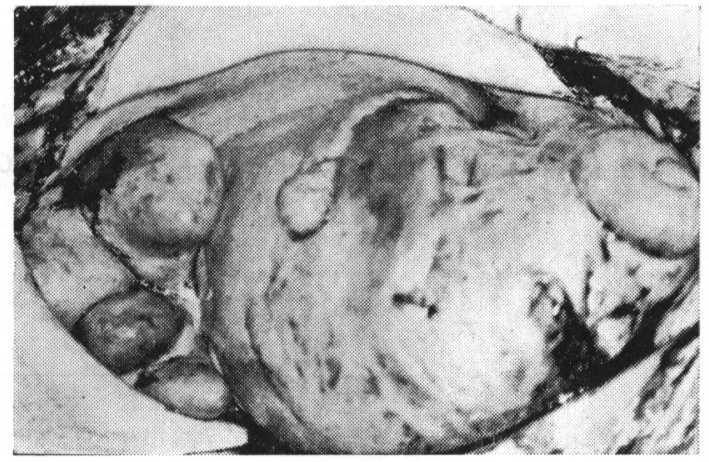

写真 2 腹膜炎後遺症

(1) 気腹前背腹 $\mathrm{X}$ 線像

(2) 気腹後 側面X線像

(3) 剖㛟図 腸管, 脾, 腎は 1 塊を示し, 肝は分葉 毎に横隔膜湳着

分することができた，骨盤腔内臟器については尾位で最 も明らかな陰影を区別することのできたのは膀脂で，つ いで病的子宮あるいは直腸であった。さらに立位では腎 および直腸ならびに子宮角の陰影を認めることができ た．これらの場合に批ける腸管の位置的な変化について は, すでに実験結果の項で述べたように, 椎骨の高さで $2 \sim 4$ コの移動があり, また, 大腸の走向にも差があっ たことはX線像を解釈する上江分考慮されねばならな いしこのために時としてバリウムを用いる腸管の造影 
を併用することも必要となる。

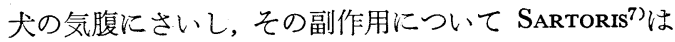
$\mathrm{O}_{2}$ を Fox tirrier の腹腔内に注入した場合, $3,000 \mathrm{~m} l$ で も不快な症候は認められなかったと報告している.今回 の実験例でも，単に空気を腹腔内に注入しただけでは血 圧・呼吸・脈搏执よび心電図にはとくに変化が認められな かった．注入後汇体位を変化させると若干の変動が記録 されたが，この程度の変動は松橋ら ${ }^{6)}$ の報告によるベン トバルビタール麻酔後空気を注入することなく単に体位 を変えただけの場合と差を認めることができなかった。 また. 人の場合立入 ${ }^{9)}$ によれば $1,000 \sim 1,5000 \mathrm{ml}$ の空気 を腹腔内に注入した場合，多少の不快感や腹部の鈍痛を 術後 1〜2 日訴えることがあるとしているが，今回の実 験例および臨床例ともに術後の食欲・元気などにとくに 変化が認められなかった.さらに手技的にBERANBAUM ら 1) は人で 206 例中 7 例で腸に刺入したとしているが，今 回はそのような失宜は全く見られなかった。これらの点 から犬に沶いても気腹による影響は比較的軽微なものと 考えられる。いっ济う，CARLSONは藏器の陰影をより見 易く，乙かも影響をより少なくするために術前 24 時間 の絶食と,できれば 12 時間内は飲水禁止をし，ヒマシ 油を投与して腸管内を空虚にしたのち，30〜40分前にモ ルヒネを与えて沈静すべきであるとしている．DougLAS は，消化管の空虚としばしば麻酔が必要であると述べて いる. 今回の実験では $12 \sim 18$ 時間の絶食ののちペント バルビタール麻酔を行なって拈り，また，臨床例の多く は1〜2 日採食していないので，そのまま無麻酔下に本 法を行ない，いずれもとくに障害を見なかった．したが って, 馴れた犬では必ずしも麻酔や沈静の必要はないと 思う。

また，術後の処置としては注入されたガス体の吸収の 問題がある，従来の報告によれば， $\mathrm{CO}_{2}$ が最も吸収が よく， $\mathrm{O}_{2}$ がこれにつぎ，空気の吸収は最も悪いとされ ている.今回の実験でも腹腔内に注入された空気は30〜 $50 \mathrm{ml} / \mathrm{kg}$ の程度しか吸収されなかった。したがって前述 のように比較的影響は少ないとはいっても，術後はでき るだけ脱気して执くことが望ましい。

以上の結果を総括するとつぎのようである.

1) 健康犬 17 頭, 臨床例 18 頭について, 空気を造 影剤として $20 \sim 130 \mathrm{ml} / \mathrm{kg}$ を腹腔内に注入し，X線撮影 をして，その像を比較検討した結果，犬では $50 \mathrm{ml} / \mathrm{kg}$ 前後注入量が適当であった.

2） 45 度の傾斜で，頭位では肝・横隔膜ときとして胃 が，尾位では膀胱，直腸および子宮が，また立位では 腎・直腸执よび子宮が観察され，とくに子宮外形の診断 には尾位怙よび立位の側面像が適していた。

3）体位により内臓の位置は相当に変化しとくに腸管 は空気注入量 $50 \mathrm{ml} / \mathrm{kg}$ で椎骨の高さで $2 \sim 4$ ב前後し
ていた.

4）気腹時の呼吸・脈搏・血圧・心電㘠については空気 注入量が $25 \sim 100 \mathrm{~m} l / \mathrm{kg}$ の範囲ではとくに変化は認めら れなかったが，注入後の体位变換に上り若干の動摇がみ。 られた。

5）注入された空気は $30 〜 50 \mathrm{ml} /$ day の割合で吸収さ れ，気腹による臨床上の影響は実験例，臨床例ともに汪: とんど認められなかった。

以上の結果から, 犬の気腹造影法は腹部の診断に有效 な方法の一つであることを知った．その実施にさいして は，術前における患犬の鎮静，空気注入時における血管 あるいは内蔵への刺入防止，さらに目的による体位およ。 び撮影方向の適正な選定などに留意する必要がある。

本研究の大要は第 146 回日本臨床獣医学会（1968年札， 幌）で報告した。

$$
\text { 参考文 献 }
$$

1) Berandaum, S.L. and P.H. Meyers. : Special Procedures in Roentgen Diagnosis, Charles C. Thomas Publisher, Illinois, (1964). 2) Carlson, W.D.: J. Am. Vet Med. Ass., 130, 245 (1957). 3) CARLson, W. D.: Veterinary. Radiology, Lea \& Febiger, Philadelphia, (1961). 4) Douglas,S.W. and H.D. Williamson.: Principles of Veterinary Radiography, Bailiere, Tindall and Cox, London: (1963). 5) Hartung, K. and G. Brendel. : Berl. and' Münch. Térärztl. Wschr., 78, 48 (1965). 6) 松橋 晧, 酒井 保: 第 67 回日本獣医学会 (1969). 7) SchNELLE, G.B.: Radiology in Small Animal Practice, North Amer. Vet., Inc. Evanston, Illinois (1950). 8) SchNelle, G.B.: North Amer. Vet., 35, 843 (1954). 9) 立入 弘 : 放射線医学入門, 南山堂, 東京 (1965)。10) 山本正 人:広島医学, 4, 468 (1951).

速報図書案内

家畜衛生の研究と実務に携わる専門家の必携書 技術の手引き 11 豊林省畜産局衛生課 共同監修

農林省家畜衛生試験堭

\section{家畜衛生に必要な}

\section{免 疫の概念と術式 6月10日発刊}

執筆：農林省家畜衛生試験場 大木与志雄, 泀か の研究執筆

$$
\text { A 5 版 約 } 200 \text { 頁 図表多数 }
$$$$
\text { 定価 } 1100 \text { 丹 (送料含) }
$$

本書は日常家畜衛生に携わる家畜保健衛生所をはじ めとする専門家のため, をた最新の知識を必要とする 獣医師はじめ,また修学の獣医学徒のために,むずかし いとされていた免疫の理論を極めて平易に解説した入 門書であり，現地で直接役立つょうにまとめた実用専 門畫である。

内容項目: 第 1 章 免疫概論一免疫抗体 抗原 抗 原抗体反応抗体の産生補体過敏症同種免疫 と疾病自己免疫病第 2 章血清反応一免疫血清 の作製抗体精製 濃縮 凝集反応穴イルス凝集 反応沈降反応免疫拡散法兔疫粘着現象 C F 䖝光抗体放射性同位元素標識抗体法第 3 章生 体内に打浼疫反応一貧食現象抗体産生細胞の 湘定法 感染防御試験と中和試験過敏症の実験法 参考書 索引
発 行
日本獣医師会 